\title{
Metabolism of glutamate and aspartate in bacteroids isolated from soybean root nodules
}

\author{
HIROSHI KoUChI, ${ }^{*}$ KatsuHIKo FuKaI $\dagger$ AND AKIHIRo KiHARA $\ddagger$ \\ Department of Applied Physiology, National Institute of Agrobiological Resources, Tsukuba, Ibaraki 305, Japan
}

(Received 2 May 1991; revised 2 September 1991; accepted 10 September 1991)

\begin{abstract}
Bacteroids were isolated anaerobically from root nodules of soybean (Glycine max L. Merr.) and supplied with ${ }^{14} \mathrm{C}$ - or ${ }^{15} \mathrm{~N}$-labelled glutamate or aspartate under microaerobic conditions where bacteroids retained a high activity of $\mathrm{N}_{2}$ fixation. Glutamate and aspartate significantly stimulated $\mathrm{N}_{2}$ fixation $\left(\mathrm{C}_{2} \mathrm{H}_{2}\right.$ reduction) and respiration $\left(\mathrm{CO}_{2}\right.$ evolution) of isolated bacteroids. They were both utilized as substrates for bacteroid respiration and their nitrogen was rapidly released from the bacteroids as $\mathrm{NH}_{3}$. Amino-oxyacetate (AOA) strongly inhibited glutamate utilization, but aspartate utilization was only slightly affected by AOA. Substantial activity of aspartate ammonia-lyase (aspartase) was detected in the cell-free extract of bacteroids. These results suggest that the major pathway of glutamate utilization in bacteroids is transamination to form aspartate followed by direct deamination of aspartate by aspartase. It is also suggested that the 4-aminobutyrate pathway (GABA-shunt) is partly responsible for the catabolism of glutamate by soybean nodule bacteroids. The results are discussed in terms of the possible relationships between $\mathrm{C}_{4}$-dicarboxylates and glutamate in carbon and nitrogen metabolism in soybean nodule bacteroids.
\end{abstract}

\section{Introduction}

Soil micro-organisms of the genera Rhizobium and Bradyrhizobium fix atmospheric $\mathrm{N}_{2}$ in a symbiotic association with leguminous plants. The bacteroids in the nodule cells utilize plant photosynthate as the energy source and develop the ability to fix $\mathrm{N}_{2}$ to supply ammonia to plant cells.

Bacteroids differ greatly from free-living Rhizobium or Bradyrhizobium bacteria with respect to carbon and nitrogen metabolism. One of the most striking differences is that bacteroids can utilize only a very limited range of carbon sources to support their respiration and $\mathrm{N}_{2}$ fixation. It is believed that the principle carbon sources utilized by bacteroids in the nodule cells are $\mathrm{C}_{4}$ dicarboxylates such as malate and succinate. This was first suggested by studies of the utilization of various carbon compounds by bacteroids isolated from nodules,

$\uparrow$ Present address: Food Research Laboratories, Mitsui Norin Co. Ltd., Fujieda, Shizuoka 426, Japan.

¥ Present address: Faculty of Agriculture and Veterinary, Nihon University, Setagaya, Tokyo 154, Japan.

Abbreviations: AOA, amino-oxyacetic acid; GABA, 4- aminobutyric acid; GABA-AT, 4-aminobutyrate aminotransferase; GDC, glutamate decarboxylase; GDH, glutamate dehydrogenase; PBM, peribacteroid membrane; PBU peribacteroid unit; SSDH; succinic semialdehyde dehydrogenase. which indicated the exclusive effectiveness of $\mathrm{C}_{4}$ dicarboxylates for respiration and $\mathrm{N}_{2}$ fixation (Tuzimura \& Meguro, 1960; Bergersen \& Turner, 1967). Studies of the dicarboxylate-transport $(d c t)$ mutants of various species of Rhizobium suggested that uptake and catabolism of $\mathrm{C}_{4}$-dicarboxylate were essential for $\mathrm{N}_{2}$ fixation by bacteroids (Ronson et al., 1981; Glenn \& Brewin, 1981; Finan et al., 1983). More recent evidence demonstrated that bacteroids isolated from soybean nodules oxidized exogenous succinate via the tricarboxylic acid (TCA) cycle, using malic enzyme to produce acetyl-CoA, even under the low oxygen concentrations required for $\mathrm{N}_{2}$ fixation (Kimura \& Tajima, 1989; Tajima et al., 1986, 1990).

On the other hand, involvement of glutamate as a possible carbon source for bacteroids in nodules has been suggested (Kahn et al., 1985; Bergersen \& Turner, 1988). We have also studied the metabolism of glutamate and aspartate by bacteroids of soybean nodules because: (1) bacteroids possess an active uptake system for glutamate (Salminen \& Streeter, 1987; Udvardi et al., 1988); (2) exogenous glutamate enhances $\mathrm{O}_{2}$ consumption and $\mathrm{N}_{2}$ fixation by isolated bacteroids (Bergersen \& Turner, 1988); (3) the site of natural ${ }^{15} \mathrm{~N}$ enrichment in soybean nodules is predominantly in the bacteroids (Reinero $e t$ al., 1983; Yoneyama et al., 1987), suggesting that 
bacteroids are supplied $\mathrm{N}$-containing compound(s) from plant cytosol and release their nitrogen through transamination and/or deamination processes (these processes are suggested to cause ${ }^{15} \mathrm{~N} /{ }^{14} \mathrm{~N}$ discrimination (Macko et al., 1983; Yoneyama et al., 1987); and (4) mutants of Rhizobium defective in glutamate catabolism form Fix $x^{-}$nodules (Kahn et al., 1985).

These data suggest that some amino compounds, most probably glutamate, are also supplied to bacteroids from plant cytosol, as well as $\mathrm{C}_{4}$-dicarboxylates. Here we describe how glutamate and aspartate are metabolized in nitrogen-fixing bacteroids, using evidence from ${ }^{14} \mathrm{C}$ and ${ }^{15} \mathrm{~N}$ tracer experiments.

\section{Methods}

Isolation of bacteroids. Soybeans (Glycine max L. Merr. var. Akisengoku) inoculated with Bradyrhizobium japonicum Al017 were grown hydroponically as described previously (Kouchi \& Yoneyama, 1986). Bacteroids were isolated anaerobically from the nodules of 40 43-d-old plants by a method modified from that of Emerich $e t$ al. (1979). All isolation procedures were carried out at $0-4{ }^{\circ} \mathrm{C}$ in a plastic cabinet under a continuous argon stream, and centrifuge tubes with airtight caps were used. The oxygen concentration in the cabinet was maintained below $0.02 \%$ (monitored by a Model LH-700H oxygen analyser, Toray). Buffers, harvested nodules and acid-washed PolyclarAT were de-gassed with a vacuum pump and saturated with argon before use. Nodules $(30 \mathrm{~g})$ were macerated with $10 \mathrm{~g}$ Polyclar-AT in $90 \mathrm{ml} 50 \mathrm{~mm}$-potassium phosphate buffer ( $\mathrm{pH} \mathrm{6.8)}$ containing $0.2 \mathrm{M}$ sodium ascorbate, $10 \mathrm{~mm}$-dithiothreitol (DTT) and $0.1 \%$ bovine serum albumin (fraction V) using a mortar and pestle. The homogenate was filtered through four layers of gauze followed by centrifugation at $500 \mathrm{~g}$ for $5 \mathrm{~min}$ at $4{ }^{\circ} \mathrm{C}$. The supernatant was further centrifuged at $9000 \mathrm{~g}$ for $10 \mathrm{~min}$. The pellet was washed three times with $90 \mathrm{ml}$ of $50 \mathrm{mM}$-MOPS$\mathrm{KOH}\left(\mathrm{pH} \mathrm{7.4)}\right.$ containing $2.5 \mathrm{~mm}-\mathrm{MgCl}_{2}, 1 \mathrm{~mm}-\mathrm{KH}_{2} \mathrm{PO}_{4}$ and $10 \mathrm{~mm}-$ DTT. The bacteroid pellets were finally suspended in $30 \mathrm{ml}$ of the same medium (8-12 $\mathrm{mg}$ protein $\mathrm{ml}^{-1}$ suspension) and stored in aliquots in liquid nitrogen until use. Bacteroids stored in liquid nitrogen retained more than $75 \%$ of their initial $\mathrm{C}_{2} \mathrm{H}_{2}$ reduction activity at least for a few months.

Assays of acetylene reduction and respiration of bacteroids. One $\mathrm{ml}$ assay medium (50 mM-MOPS-KOH, $2.5 \mathrm{mM}-\mathrm{MgCl}_{2}$ and $1 \mathrm{mM}-$ $\mathrm{KH}_{2} \mathrm{PO}_{4}, \mathrm{pH} 7.4$ ) with or without exogenous substrates was placed in a serum bottle ( $22 \mathrm{ml}$ volume) with a double rubber cap. The head space was evacuated and then re-filled with argon. This procedure was repeated four times, after which acetylene was introduced to a final concentration of $10 \%(\mathrm{v} / \mathrm{v})$. Appropriate volumes of oxygen were injected with a gas tight syringe. Reaction was started with an injection of $0.1 \mathrm{ml}$ bacteroid suspension (about $1 \mathrm{mg}$ bacteroid protein) followed by incubation at $28^{\circ} \mathrm{C}$ for $20 \mathrm{~min}$ with vigorous shaking (on a reciprocating shaker, 190 r.p.m.). The reaction was stopped by injecting $0.1 \mathrm{ml} 60 \%(\mathrm{w} / \mathrm{v}) \mathrm{H}_{2} \mathrm{SO}_{4}$. After a further $20 \mathrm{~min}$ incubation to liberate $\mathrm{CO}_{2}$ dissolved in the medium, $1 \mathrm{ml}$ of the head space gas was analysed by gas chromatography (model GC-3, Shimadzu) with a $2 \mathrm{~m}$ stainless-steel column packed with Porapak R. A short column packed with a nickel catalyst (Shimarite, Shimadzu) was inserted between the Porapak R column and a flame ionization detector (FID) and heated at $700^{\circ} \mathrm{C}$ in a reaction furnace. Using hydrogen as a carrier gas, $\mathrm{CO}_{2}$ was reduced to $\mathrm{CH}_{4}$ and detected by a FID, as well as $\mathrm{C}_{2} \mathrm{H}_{4}$. All measurements were made for at least duplicate incubations.
Radiorespirometric experiments. Respiratory evolution of ${ }^{14} \mathrm{CO}_{2}$ from bacteroids fed ${ }^{14} \mathrm{C}$-labelled substrates was measured with the same incubation system as for the assay of $\mathrm{C}_{2} \mathrm{H}_{2}$ reduction and respiration. The head space was filled with $\mathrm{N}_{2}$ instead of $\mathrm{C}_{2} \mathrm{H}_{2} / \mathrm{Ar}$ and oxygen concentrations were adjusted to ensure maximum $\mathrm{C}_{2} \mathrm{H}_{2}$ reduction activity. After incubation, I $\mathrm{ml}$ of the head space gas was withdrawn and injected into a scintillation vial containing $0.5 \mathrm{ml}$ monoethanolamine-methylcellosolve $(1: 2, \mathrm{v} / \mathrm{v})$ through a double rubber cap. After the vials had been agitated for $10 \mathrm{~min}$ at room temperature, $10 \mathrm{ml}$ toluene scintillator was added and the radioactivity was measured with a liquid scintillation counter.

${ }^{14} \mathrm{C}$ and ${ }^{15} \mathrm{~N}$ labelling experiments and amino acid analysis. One $\mathrm{ml}$ (about $10 \mathrm{mg}$ protein) bacteroid suspension was incubated with $5 \mathrm{ml}$ assay medium containing ${ }^{14} \mathrm{C}$ - or ${ }^{15} \mathrm{~N}$-labelled substrates in $100 \mathrm{ml}$ serum bottles. The head space was filled with $\mathrm{N}_{2}$ containing $1.5 \%(\mathrm{v} / \mathrm{v})$ $\mathrm{O}_{2}$. After incubation, bacteroids wre pelleted immediately by centrifugation at $10000 \mathrm{~g}$ for $5 \mathrm{~min}$ at $4{ }^{\circ} \mathrm{C}$. The bacteroid pellets were washed once with $10 \mathrm{mM}$-sodium phosphate buffer $(\mathrm{pH} \mathrm{7.4)}$ ) followed by extraction with $80 \%(v / v)$ ethanol in a boiling-water bath for $20 \mathrm{~min}$. After centrifugation, the ethanol extracts were evaporated in vacuo and fractionated into neutral, acidic and basic fractions with ion-exchange resins (Wang, 1960).

In ${ }^{14} \mathrm{C}$-labelling experiments, amino acids in the basic fraction were separated by two-dimensional TLC (Kano et al., 1975) and detected by spraying with $o$-phthalaldehyde solution (Mori et al., 1977). Individual amino acid spots were scraped off into toluene scintillator to measure radioactivity. Abundances of ${ }^{15} \mathrm{~N}$ in amino acids were determined by gas chromatography-mass spectrometry (Kouchi \& Yoneyama, 1984). Absolute amounts of amino acids were determined with an automatic amino acid analyser (model L8500, Hitachi).

The concentration of and abundance of ${ }^{15} \mathrm{~N}$ in $\mathrm{NH}_{3}$ in the incubation medium were determined by the indophenol method (Weatherburn, 1967) and emission spectrometry (Yoneyama et al., 1975), respectively, after trapping $\mathrm{NH}_{3}$ in $0.2 \mathrm{M}-\mathrm{HCl}$ by microdiffusion (Yoneyama et al., 1975).

Isolation of peribacteroid-membrane (PBM)-enclosed bacteroids. The isolation procedure for PBM-enclosed bacteroids (peribacteroid unit, PBU) was based on that of Price et al. (1987) with some modifications. All isolation procedures were carried out at $4{ }^{\circ} \mathrm{C}$ under aerobic conditions and a refrigerated centrifuge (05PR-22, Hitachi) equipped with a swinging bucket rotor (type 05 , Hitachi) was used. Nodules (15$20 \mathrm{~g}$ ) harvested from 40-43-d-old plants were homogenized very gently in homogenization medium with a porcelain mortar (with rough surface) and a wooden pestle. The homogenization medium comprised $100 \mathrm{~mm}$-MOPS-KOH (pH 7.2) containing $0.375 \mathrm{M}$-mannitol, $10 \mathrm{~mm}$ $\mathrm{MgSO}_{4}, 10 \mathrm{~mm}$-EGTA, $10 \mathrm{~mm}$-DTT, $1 \%(\mathrm{w} / \mathrm{v})$ polyvinylpyrrolidone (PVP-40, Sigma), $0.5 \%(w / v)$ bovine serum albumin and $4 \%(w / v)$ dextran T40 (Pharmacia). The homogenate was passed through two layers of Miracloth (Calbiochem) followed by centrifugation at $160 \mathrm{~g}$ for $15 \mathrm{~min}$ to remove unbroken tissues and cell debris. The supernatant was further centrifuged at $680 \mathrm{~g}$ for $10 \mathrm{~min}$. The pellet was gently suspended in $10 \mathrm{ml}$ washing medium consisting of $20 \mathrm{mM}-\mathrm{MOPS}-\mathrm{Bis}-$

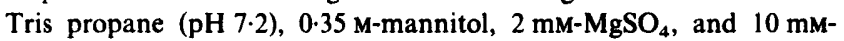
$\mathrm{KCl}$. Five $\mathrm{ml}$ of the suspension was layered on a discontinuous gradient consisting of $4 \mathrm{ml} 45 \%(\mathrm{v} / \mathrm{v}), 5 \mathrm{ml} 60 \%$ and $1 \mathrm{ml} 80 \%$ Percoll in the washing medium, and centrifuged at $4200 \mathrm{~g}$ for $17 \mathrm{~min}$ at $4{ }^{\circ} \mathrm{C}$. The PBUs migrated to the $60 / 80 \%$ interphase and $80 \%$ layer, and were collected using a wide-bore pipette and resuspended in 10 vols washing medium. The suspension was layered onto $1 \mathrm{ml} 80 \%$ Percoll and centrifuged at $680 \mathrm{~g}$ for $5 \mathrm{~min}$. The PBU pellets on the Percoll cushion were resuspended in $20-30 \mathrm{ml}$ washing medium and centrifuged at $420 \mathrm{~g}$ for $5 \mathrm{~min}$. The final pellet of PBUs was suspended in appropriate volumes of washing medium. The PBUs were kept on ice and used within $1 \mathrm{~h}$. 
Assays of utilization of malate and glutamate by intact PBUs. One $\mathrm{ml}$ PBU suspension was placed in a serum bottle $(12.5 \mathrm{ml}$ volume $)$ with a double rubber cap. The bottles were preincubated for $3 \mathrm{~min}$ at $27^{\circ} \mathrm{C}$ and the reaction was started by injection of $3 \mu \mathrm{Ci}(0.11 \mathrm{MBq})$ $\left[{ }^{4} \mathrm{C}\right]$ malate or $\left[{ }^{1+} \mathrm{C}\right]$ glutamate (final concentrations of 2 or $0.1 \mathrm{~mm}$ ). After incubation at $27^{\circ} \mathrm{C}$ with gentle shaking (30 r.p.m.), the reaction was stopped by injection of $100 \mu \mathrm{l} 60 \%(\mathrm{w} / \mathrm{v}) \mathrm{H}_{2} \mathrm{SO}_{4}$ followed by $20 \mathrm{~min}$ incubation with vigorous agitation. The radioactivity of the head space gas was determined as described above. The same experiment was conducted in parallel using naked bacteroids prepared from the same PBU preparation by 2 min agitation in washing medium with a vortex mixer (Udvardi et al., 1988).

Enzyme assays. Nodules ( $40 \mathrm{~d}$-old) were homogenized in $100 \mathrm{~mm}$ MOPS- $\mathrm{KOH}$ ( $\mathrm{pH} 7.2$ ) containing $0.3 \mathrm{M}$-mannitol, $10 \mathrm{mM}-\mathrm{MgCl}_{2}$ and $10 \mathrm{~mm}$-DTT with a mortar and pestle. The homogenates were passed through four layers of gauze followed by centrifugation at $9000 \mathrm{~g}$ for 10 min at $4{ }^{\circ} \mathrm{C}$. Precipitated bacteroids were suspended in the same medium and further purified by centrifugation on a discontinuous Percoll gradient (Kouchi \& Fukai, 1989). Purified bacteroids were suspended in $50 \mathrm{~mm}-\mathrm{MOPS}-\mathrm{KOH}\left(\mathrm{pH} \mathrm{7.2)}\right.$ containing $10 \mathrm{~mm}-\mathrm{MgCl}_{2}$, $10 \mathrm{~mm}$-DTT and $\mathrm{l} \%(\mathrm{v} / \mathrm{v})$ Triton $\mathrm{X}-100$, and disrupted in an ultrasonic homogenizer (a Sonifier Model 250, Branson) for $2 \mathrm{~min}$ at $60 \mathrm{~W}$ output on ice. After centrifugation at $12000 \mathrm{~g}$ for $15 \mathrm{~min}$ at $4{ }^{\circ} \mathrm{C}$, the supernatants were used as the bacteroid crude extracts. The supernatants after the first centrifugation of the nodule homogenate were further centrifuged at $21000 \mathrm{~g}$ for $10 \mathrm{~min}$ at $4{ }^{\circ} \mathrm{C}$ and used as the cytosol fraction. The cytosol and bacteroid extracts were passed through a Sephadex G-25 column prior to enzyme assays.

The methods for enzyme assays were as follows: aspartateoxoglutarate aminotransferase (EC 2.6.1.1) and alanine-oxoglutarate aminotransferase (EC 2.6.1.2), Holtum \& Winter (1982); glutamate dehydrogenase (GDH, EC 1 4. 1 .3), Dunn \& Klucas (1973); glutamate decarboxylase (GDC, EC 4.1.1.15) and succinic semialdehyde dehydrogenase (SSDH, EC 1.2.1.24), Streeter \& Thompson (1972); and 4-aminobutyrate aminotransferase (GABA-AT, EC 2.6.1.19), Freney \& Gibson (1975). Aspartate ammonia-lyase (aspartase, EC 4.3.1.1) was assayed as described by Tokushige (1985) by determining released ammonium ions by the Nessler method (Le Page, 1964). The protein concentrations were determined as described by Bradford (1976) using bovine serum albumin as a standard.

\section{Results}

Table I summarizes the effects of various carbon sources on the bacteroid activities $\left(\mathrm{C}_{2} \mathrm{H}_{2}\right.$ reduction and $\mathrm{CO}_{2}$ evolution) as well as on the $\mathrm{O}_{2}$ concentrations giving the maximum $\mathrm{C}_{2} \mathrm{H}_{2}$ reducing activity. Succinate, malate, fumarate and oxaloacetate had the most significant effect on the bacteroid activities. $\mathrm{C}_{2} \mathrm{H}_{2}$ reduction activity of isolated bacteroids increased three times or more by supplying these carboxylates. Some other carboxylates also stimulated the bacteroid activities but were less effective than these four carboxylates, whereas pyruvate and glyoxylate had no significant effect.

Other than the TCA cycle carboxylates, four amino acids, glutamate, aspartate, glutamine and asparagine significantly increased the bacteroid activities. When bacteroids were supplied glutamine or asparagine, they

Table 1. Effects of various carbon sources on $\mathrm{C}_{2} \mathrm{H}_{2}$ reduction activity and respiration ( $\mathrm{CO}_{2}$ evolution) of isolated bacterioids

Data are expressed as means \pm SE of eight (for the control values with no substrate) or duplicate measurements. The assay system is described in Methods.

\begin{tabular}{|c|c|c|c|c|}
\hline Substrate & $\begin{array}{l}\text { Concn } \\
(\mathrm{mM})\end{array}$ & $\underset{(\%)}{\mathrm{O}_{2} \text {-optimum }}$ & $\begin{array}{c}\mathrm{C}_{2} \mathrm{H}_{4} \text { formation } \\
{\left[\mu \mathrm{mol} \mathrm{h}{ }^{-1}(\text { mg protein })^{-1}\right]}\end{array}$ & $\begin{array}{c}\mathrm{CO}_{2} \text { evolution } \\
{\left[\mu \mathrm{mol} \mathrm{h}{ }^{-1}(\text { mg protein })^{-1}\right.}\end{array}$ \\
\hline None & & $0 \cdot 42$ & $0.11 \pm 0.003$ & $0.97 \pm 0.002$ \\
\hline Acetate & $2 \cdot 0$ & 0.55 & $0 \cdot 14 \pm 0 \cdot 02$ & $1 \cdot 40 \pm 0 \cdot 15$ \\
\hline Pyruvate & $2 \cdot 0$ & 0.43 & $0 \cdot 10 \pm 0 \cdot 02$ & $1 \cdot 20 \pm 0 \cdot 12$ \\
\hline Succinate & $2 \cdot 0$ & 1.02 & $0.35 \pm 0.06$ & $2.75 \pm 0.23$ \\
\hline Malate & $2 \cdot 0$ & 0.94 & $0 \cdot 33 \pm 0.03$ & $2.74 \pm 0.44$ \\
\hline Fumarate & $2 \cdot 0$ & 0.84 & $0.42 \pm 0.05$ & $3.31 \pm 0.29$ \\
\hline Oxaloacetate & $2 \cdot 0$ & 0.66 & $0.38 \pm 0.06$ & $2.67 \pm 0.38$ \\
\hline 2-Oxoglutarate & $2 \cdot 0$ & $0 \cdot 84$ & $0.11 \pm 0.01$ & $1.26 \pm 0.22$ \\
\hline Citrate & $2 \cdot 0$ & 0.81 & $0.24 \pm 0.03$ & $2 \cdot 18 \pm 0.15$ \\
\hline 3-Hydroxybutyrate & $3 \cdot 0$ & $0 \cdot 84$ & $0 \cdot 17 \pm 0 \cdot 02$ & $1.19 \pm 0.08$ \\
\hline Glyoxylate & $2 \cdot 0$ & $0 \cdot 41$ & $0 \cdot 10 \pm 0 \cdot 01$ & $1 \cdot 10 \pm 0 \cdot 17$ \\
\hline $\begin{array}{l}\text { Succinic } \\
\text { semialdehyde }\end{array}$ & $2 \cdot 0$ & 0.92 & $0.28 \pm 0.03$ & $2.51 \pm 0.32$ \\
\hline Glutamate & $\begin{array}{l}0 \cdot 2 \\
2 \cdot 0\end{array}$ & $\begin{array}{l}0 \cdot 48 \\
0 \cdot 74\end{array}$ & $\begin{array}{l}0 \cdot 16 \pm 0.00 \\
0 \cdot 21 \pm 0.03\end{array}$ & $\begin{array}{l}1 \cdot 14 \pm 0 \cdot 18 \\
2 \cdot 02 \pm 0 \cdot 16\end{array}$ \\
\hline Glutamine & $\begin{array}{l}0 \cdot 2 \\
2 \cdot 0\end{array}$ & $\begin{array}{l}0.76 \\
0.82\end{array}$ & $\begin{array}{l}0 \cdot 26 \pm 0.01 \\
0 \cdot 21 \pm 0.02\end{array}$ & $\begin{array}{l}1.69 \pm 0.09 \\
1.99 \pm 0.18\end{array}$ \\
\hline Aspartate & $\begin{array}{l}0 \cdot 2 \\
2 \cdot 0\end{array}$ & $\begin{array}{l}0.57 \\
0.70\end{array}$ & $\begin{array}{l}0.25 \pm 0.05 \\
0 \cdot 20 \pm 0.02\end{array}$ & $\begin{array}{l}1 \cdot 71 \pm 0 \cdot 20 \\
2 \cdot 18 \pm 0 \cdot 27\end{array}$ \\
\hline Asparagine & $\begin{array}{l}0 \cdot 2 \\
2 \cdot 0\end{array}$ & $\begin{array}{l}0.57 \\
0.80\end{array}$ & $\begin{array}{l}0.25 \pm 0.03 \\
0.18 \pm 0.01\end{array}$ & $\begin{array}{l}1 \cdot 71 \pm 0 \cdot 11 \\
2 \cdot 18 \pm 0 \cdot 10\end{array}$ \\
\hline $\begin{array}{l}\text { 4-Aminobutyrate } \\
\text { Alanine }\end{array}$ & $\begin{array}{l}2 \cdot 0 \\
2 \cdot 0\end{array}$ & $\begin{array}{l}0 \cdot 39 \\
0 \cdot 49\end{array}$ & $\begin{array}{l}0.14 \pm 0.00 \\
0 \cdot 13 \pm 0.02\end{array}$ & $\begin{array}{l}0.98 \pm 0.13 \\
1.07 \pm 0.09\end{array}$ \\
\hline
\end{tabular}



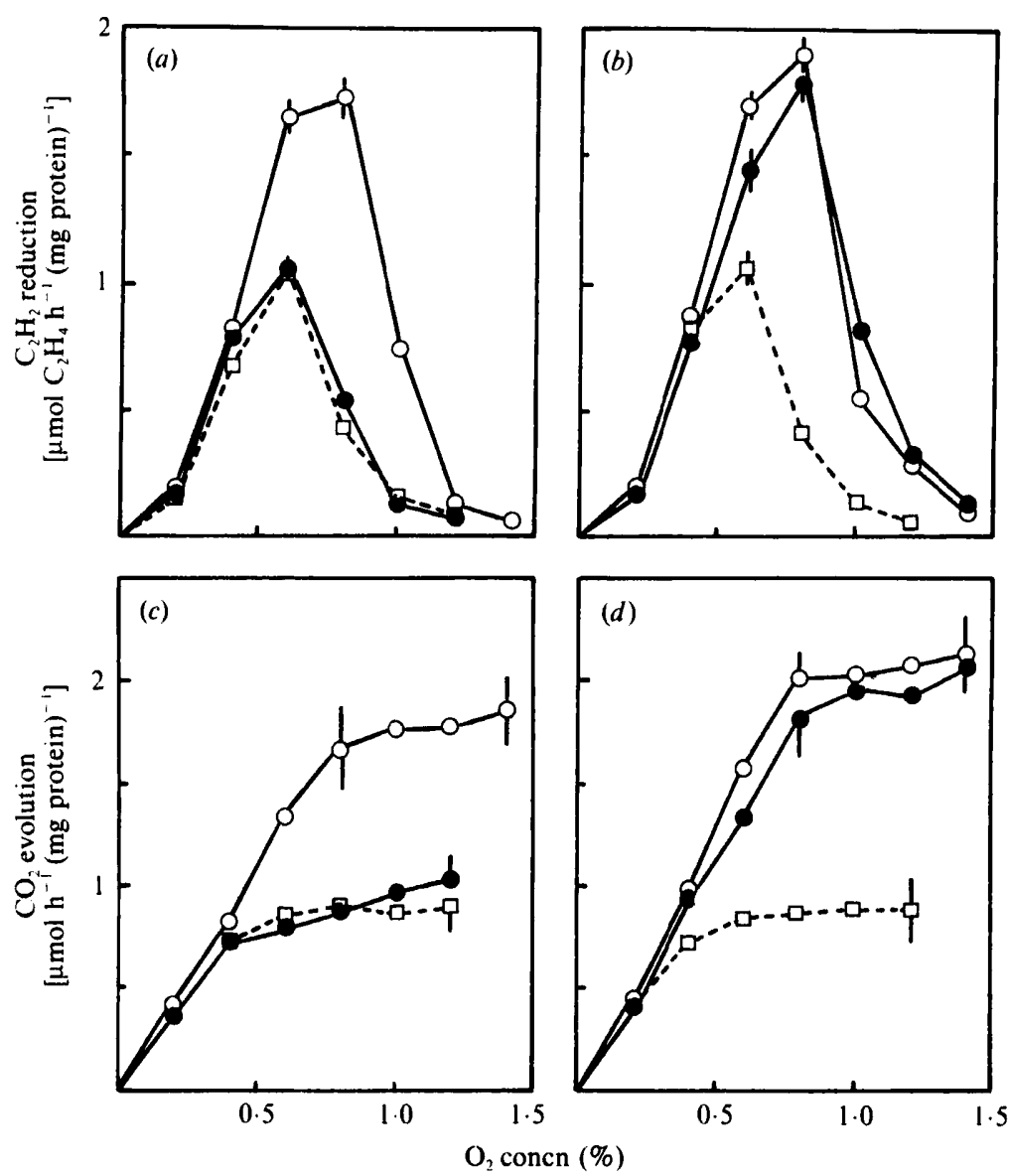

Fig. 1. Effects of glutamate $(a, c)$ and aspartate $(b, d)$, with or without $\mathrm{AOA}$, on $\mathrm{C}_{2} \mathrm{H}_{2}$ reduction $(a, b)$ and $\mathrm{CO}_{2}$ evolution $(c, d)$ by bacteroids isolated from soybean root nodules. ( $\square$ ), Endogenous activities (no added substrate); (O), $2 \mathrm{mM}$-glutamate or aspartate; (O), $2 \mathrm{mM}$ glutamate or aspartate with $3 \mathrm{~mm}$-AOA. Data are expressed as means of duplicate incubations. Vertical bars indicate $2 \times$ SE. The assay system is described in Methods. were converted very rapidly to glutamate or aspartate, respectively in the medium (data not shown), suggesting that these amides were utilized by bacteroids mainly after rapid deamidation in the supernatant of the bacteroid suspension.

The effect of amino-oxyacetate (AOA) as a specific inhibitor of transamination on glutamate- or aspartatedependent $\mathrm{C}_{2} \mathrm{H}_{2}$ reduction and $\mathrm{CO}_{2}$ evolulion was examined (Fig. 1). The addition of AOA ( $3 \mathrm{mM}$ ) in the incubation medium decreased glutamate-dependent bacteroid activities to the endogenous levels but had no effect on aspartate-dependent ones. Similar effects of AOA on the utilization of glutamate and aspartate as respiratory substrates for bacteroids were observed in radiorespirometric experiments (Fig. 2). The addition of AOA resulted in an approximately $60 \%$ decrease in ${ }^{14} \mathrm{CO}_{2}$ evolution from glutamate, whereas utilization of aspartate was only slightly affected by AOA.

Table 2 shows the incorporation of ${ }^{15} \mathrm{~N}$ into free amino acids in the bacteroids supplied with $\left[{ }^{15} \mathrm{~N}\right]$ glutamate or $\left[{ }^{15} \mathrm{~N}\right]$ aspartate, as well as into $\mathrm{NH}_{3}$ in the medium. The largest amount of ${ }^{15} \mathrm{~N}$ was found in $\mathrm{NH}_{3}$ in the medium. The abundances and absolute amounts of ${ }^{15} \mathrm{~N}$ in $\mathrm{NH}_{3}$ in the medium were both much higher in the incubation with $\left[{ }^{15} \mathrm{~N}\right]$ aspartate than with $\left[{ }^{15} \mathrm{~N}\right]$ glutamate. The distributions of ${ }^{15} \mathrm{~N}$ in individual amino acids were very similar in aspartate-and glutamate-fed bacteroids. The highest ${ }^{15} \mathrm{~N}$ abundance was found in glutamate and 4-aminobutyrate. Since glutamate is the largest pool among bacteroid amino acids (Kouchi \& Yoneyama, 1986; Streeter, 1987), most of the ${ }^{15} \mathrm{~N}$ in the bacteroids was in glutamate. The amount of label in aspartate was very low even in the bacteroids fed $\left[{ }^{15} \mathrm{~N}\right]$ aspartate. The same experiments were conducted with or without AOA (Table 3). AOA greatly decreased ${ }^{15} \mathrm{~N}$ abundance in amino acids in the bacteroids other than exogenously supplied amino acids, indicating that transamination reactions in bacteroids were effectively inhibited by AOA. In the incubation with $\left[{ }^{15} \mathrm{~N}\right]$ glutamate, AOA greatly decreased labelling of $\mathrm{NH}_{3}$ in the medium, whereas ${ }^{15} \mathrm{NH}_{3}$ liberation from $\left[{ }^{15} \mathrm{~N}\right]$ aspartate was affected much less.

Since the results of the inhibition experiments using AOA suggested the direct deamination of aspartate, the presence of aspartase in bacteroids was examined (Table 4). Cell-free extract of bacteroids passed through a Sephadex G-25 column showed substantial activity of aspartase and, as expected, this activity was not 


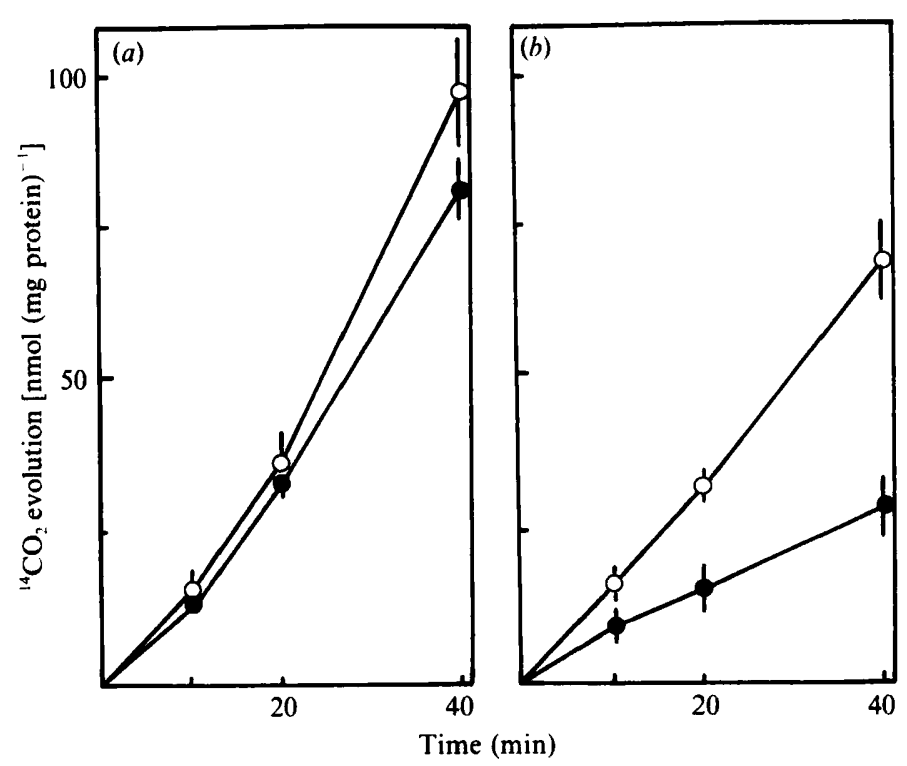

Fig. 2. Respiratory utilization of $\left[{ }^{14} \mathrm{C}\right]$ aspartate $(a)$ and $\left[{ }^{14} \mathrm{C}\right]$ glutamate $(b)$ by isolated bacteroids with $(O)$ or without (O) $3 \mathrm{~mm}$-AOA. Bacteroids $(0 \cdot 1 \mathrm{ml}$ suspension with $1 \mathrm{ml}$ assay medium) were incubated with $2 \mathrm{~mm}-\left[\mathrm{U}-{ }^{14} \mathrm{C}\right]$ aspartate or [U${ }^{14} \mathrm{C}$ glutamate $(0.2 \mu \mathrm{Ci}, 7.4 \mathrm{kBq})$ under $0.8 \% \mathrm{O}_{2}$ in $\mathrm{N}_{2}$. Data are expressed as means of duplicate incubations. Vertical bars indicate $2 \times \mathrm{SE}$.

Table 2. Incorporation of ${ }^{15} \mathrm{~N}$ into free amino acids in the bacterioids and $\mathrm{NH}_{3}$ in the incubation medium

The bacterioids ( $\mathrm{ml}$ suspension) were incubated with $5 \mathrm{ml}$ assay medium containing [ $\left.{ }^{15} \mathrm{~N}\right]$ aspartate or $\left[{ }^{15} \mathrm{~N}\right] \mathrm{glutamate}$ $\left(2 \mathrm{mM}, 52.7\right.$ atom \%) under $1.5 \% \mathrm{O}_{2}$ in $\mathrm{N}_{2}$. Data are expressed as means $\pm \mathrm{SE}$ of duplicate experiments. Absolute amounts of ${ }^{15} \mathrm{~N}$ [nmol (mg protein $)^{-1}$ ] are shown in parentheses except values $<0.1 \mathrm{nmol}$.

\begin{tabular}{|c|c|c|c|c|}
\hline \multirow[b]{3}{*}{ Amino acid } & \multicolumn{4}{|c|}{ Incorporation of ${ }^{15} \mathrm{~N}($ atom $\%)$} \\
\hline & \multicolumn{2}{|c|}{ Aspartate } & \multicolumn{2}{|c|}{ Glutamate } \\
\hline & $10 \mathrm{~min}$ & $20 \mathrm{~min}$ & $10 \mathrm{~min}$ & $20 \mathrm{~min}$ \\
\hline Asp & $5.9 \pm 0.57$ & $\begin{array}{l}10 \cdot 1 \pm 2 \cdot 03 \\
(0 \cdot 1)\end{array}$ & $5.8 \pm 0.78$ & $\begin{array}{l}10 \cdot 1 \pm 0 \cdot 19 \\
(0 \cdot 1)\end{array}$ \\
\hline Thr & $3 \cdot 5 \pm 0 \cdot 14$ & $4.8 \pm 0.13$ & $2.8 \pm 0.01$ & $4.1 \pm 0.80$ \\
\hline Ser & $0.9 \pm 0.21$ & $2.6 \pm 0.15$ & $1.3 \pm 0.41$ & $2 \cdot 2 \pm 0.36$ \\
\hline Glu & $\begin{array}{l}20 \cdot 3 \pm 3.08 \\
(2.9)\end{array}$ & $\begin{array}{l}26 \cdot 2 \pm 1 \cdot 26 \\
(4 \cdot 4)\end{array}$ & $\begin{array}{l}28.5 \pm 0.69 \\
(4.4)\end{array}$ & $\begin{array}{l}32.0 \pm 0.09 \\
(5.9)\end{array}$ \\
\hline Gly & $1 \cdot 1 \pm 0.01$ & $1.3 \pm 0.01$ & $0.9 \pm 0.18$ & $1 \cdot 3 \pm 0.07$ \\
\hline Ala & $\begin{array}{l}6.7 \pm 0.21 \\
(0.5)\end{array}$ & $\begin{array}{l}9.6 \pm 0.92 \\
(0.7)\end{array}$ & $\begin{array}{l}8.9 \pm 0.04 \\
(0.6)\end{array}$ & $\begin{array}{l}11.6 \pm 0.13 \\
(0.8)\end{array}$ \\
\hline Val & $\begin{array}{l}9.6 \pm 0.25 \\
(0.2)\end{array}$ & $\begin{array}{l}12 \cdot 1 \pm 0 \cdot 28 \\
(0 \cdot 2)\end{array}$ & $\begin{array}{l}9 \cdot 3 \pm 0.03 \\
(0.2)\end{array}$ & $\begin{array}{l}11 \cdot 3 \pm 0.06 \\
(0.2)\end{array}$ \\
\hline Ile & $\begin{array}{l}10 \cdot 4 \pm 1 \cdot 29 \\
(0 \cdot 1)\end{array}$ & $\begin{array}{l}12 \cdot 1 \pm 2 \cdot 40 \\
(0 \cdot 2)\end{array}$ & $\begin{array}{l}15 \cdot 0 \pm 0 \cdot 20 \\
(0 \cdot 2)\end{array}$ & $\begin{array}{l}18 \cdot 6 \pm 0.77 \\
(0.2)\end{array}$ \\
\hline Leu & $\begin{array}{l}8 \cdot 7 \pm 0 \cdot 28 \\
(0 \cdot 1)\end{array}$ & $\begin{array}{l}12 \cdot 0 \pm 1.33 \\
(0.2)\end{array}$ & $\begin{array}{l}11 \cdot 3 \pm 0.35 \\
(0.1)\end{array}$ & $\begin{array}{l}14.5 \pm 0.04 \\
(0.2)\end{array}$ \\
\hline GABA & $22 \cdot 1 \pm 0 \cdot 35$ & $27.7 \pm 0.91$ & $28.5 \pm 0.63$ & $33 \cdot 6 \pm 0.22$ \\
\hline $\begin{array}{l}\mathrm{NH}_{3} \text { in the } \\
\text { medium }\end{array}$ & $\begin{array}{l}30 \cdot 0 \pm 1.00 \\
(16 \cdot 4)\end{array}$ & $\begin{array}{l}30.5 \pm 0.05 \\
(26.7)\end{array}$ & $\begin{array}{l}21.8 \pm 0.30 \\
(6.7)\end{array}$ & $\begin{array}{l}24.6 \pm 0.60 \\
(13.5)\end{array}$ \\
\hline
\end{tabular}

inhibited by AOA. On the other hand, aspartase activity in plant cell cytosol was very low.

Incorporation of ${ }^{14} \mathrm{C}$ from $\left[{ }^{14} \mathrm{C}\right]$ aspartate, $\left[{ }^{14} \mathrm{C}\right]$ glutamate and $\left[{ }^{14} \mathrm{C}\right]$ malate into soluble fractions of bacteroids is shown in Table 5 . The highest radioactivity was found in cationic fractions and the largest amount of ${ }^{14} \mathrm{C}$ was present in glutamate in all experiments.
Table 6 shows amino acid concentrations in bacteroids and in the medium after incubation with malate, glutamate or malate plus glutamate. Glutamate was the most abundant amino acid in the bacteroids in all treatments and increased greatly by incubating with glutamate. Alanine in bacteroids also increased slightly by incubating with malate but the concentrations of 
Table 3. Incorporation of ${ }^{15} \mathrm{~N}$ into free amino acids in the bacteroids fed $\left[{ }^{15} \mathrm{~N}\right.$ aspartate or $\left[{ }^{15} \mathrm{~N}\right]$ glutamate with or without $\mathrm{AOA}$, and in $\mathrm{NH}_{3}$ liberated into the medium

The bacteroids ( $1 \mathrm{ml}$ suspension) were incubated with $5 \mathrm{ml}$ assay medium containing [ ${ }^{5} \mathrm{~N}$ ]aspartate or [ $\left.{ }^{15} \mathrm{~N}\right]$ glutamate $\left(3 \mathrm{mM}, 52.7\right.$ atom $\%$ ) with or without $5 \mathrm{mM}$-AOA for $20 \mathrm{~min}$ under $1.5 \% \mathrm{O}_{2}$ in $\mathrm{N}_{2}$. Data are expressed as means \pm SE of duplicate experiments.

\begin{tabular}{|c|c|c|c|c|}
\hline \multirow[b]{3}{*}{ Amino acid } & \multicolumn{4}{|c|}{ Incorporation of ${ }^{15} \mathrm{~N}$ (atom $\%$ ) } \\
\hline & \multicolumn{2}{|c|}{ Aspartate } & \multicolumn{2}{|c|}{ Glutamate } \\
\hline & $-\mathrm{AOA}$ & $+\mathrm{AOA}$ & $-\mathrm{AOA}$ & $+\mathrm{AOA}$ \\
\hline Asp & $5 \cdot 2 \pm 0 \cdot 38$ & $12.5 \pm 0.43$ & $8 \cdot 3 \pm 1 \cdot 17$ & $3.7 \pm 0.77$ \\
\hline Thr & $4.0 \pm 0.91$ & $3.9 \pm 0.51$ & $2 \cdot 5 \pm 0.24$ & $0.1 \pm 0.05$ \\
\hline Ser & $0.3 \pm 0.02$ & 0.0 & $0.7 \pm 0.21$ & $0.2+0.11$ \\
\hline Glu & $31.8 \pm 0.42$ & $9.2 \pm 0.45$ & $35.0 \pm 0.15$ & $38.7 \pm 0.68$ \\
\hline Gly & $1.0 \pm 0.10$ & $0.5 \pm 0.30$ & $1 \cdot 1 \pm 0.06$ & $0.6 \pm 0.06$ \\
\hline Ala & $7.2 \pm 0.19$ & $3.1 \pm 0.01$ & $10.1 \pm 0.48$ & $1.6 \pm 0.20$ \\
\hline Val & $10.4 \pm 0.63$ & $2 \cdot 2 \pm 0.03$ & $10.3 \pm 0.29$ & $3 \cdot 3 \pm 0.30$ \\
\hline Ile & $12.3 \pm 1.47$ & $2.0 \pm 1.01$ & $17 \cdot 1 \pm 0.87$ & $4.8 \pm 0.72$ \\
\hline Leu & $6.8 \pm 0.02$ & $1.7 \pm 0.41$ & $11.7 \pm 0.03$ & $4.0 \pm 0.50$ \\
\hline GABA & $26.5 \pm 0.08$ & $4 \cdot 2 \pm 0 \cdot 13$ & $32 \cdot 8 \pm 0.06$ & $4.7 \pm 0.06$ \\
\hline $\begin{array}{l}\mathrm{NH}_{3} \text { in the } \\
\text { medium }\end{array}$ & $30 \cdot 2 \pm 0 \cdot 45$ & $20 \cdot 8 \pm 0 \cdot 35$ & $25 \cdot 3 \pm 0 \cdot 20$ & $6 \cdot 2 \pm 0 \cdot 12$ \\
\hline
\end{tabular}

Table 4. Aspartate ammonia-lyase (aspartase) activities in plant cell cytosol and bacteroids of soybean root nodules

The reaction mixture $(1 \mathrm{ml})$ consisted of $100 \mathrm{~mm}-\mathrm{Tris} / \mathrm{HCl}$ (pH 8.8), $100 \mathrm{~mm}$-sodium aspartate, $2 \mathrm{~mm}-\mathrm{MgCl}_{2}, 5 \mathrm{mM}-\mathrm{KCl}$ and $50 \mu \mathrm{l}$ crude extract of cytosol or bacteroids. After the incubation at $30{ }^{\circ} \mathrm{C}$ for $30 \mathrm{~min}, \mathrm{NH}_{3}$ released was determined colorimetrically by the Nessler method. The extracts, after boiling for $5 \mathrm{~min}$, were used as a control. Data for duplicate assays are shown.

\begin{tabular}{lcc}
\hline \hline & \multicolumn{2}{c}{ Aspartase activity } \\
& {$\left[\mathrm{nmol} \mathrm{\textrm {NH } _ { 3 } ( \mathrm { mg } \text { protein } ) ^ { - 1 }} \mathrm{min}^{-1}\right]$} \\
\cline { 2 - 3 } & Cytosol & Bacteroid \\
\hline - AOA & 5.1 & 54.5 \\
+ AOA (1 mM) & 3.9 & 59.1 \\
& 3.8 & 59.1 \\
\hline \hline
\end{tabular}

other amino acids were not significantly affected by exogenous substrates. When bacteroids were incubated with malate, alanine markedly accumulated in the medium, whereas aspartate accumulated in the medium during the incubation with glutamate. The accumulation of aspartate and alanine in the medium increased greatly when bacteroids were incubated with malate plus glutamate.

Enzyme activities relating to glutamate catabolism in the bacteroids were assayed (Table 7). The activities of GDH and aspartate-oxoglutarate aminotransferase were similar in plant cell cytosol and bacteroids on a total protein basis. Glutamate decarboxylase, the first enzyme of the 4-aminobutyrate pathway (GABA shunt) was at
Table 5. Incorporation of ${ }^{14} \mathrm{C}$ into soluble fractions of bacteroids from $\left[{ }^{14} \mathrm{C}\right]$ aspartate, $\left[{ }^{14} \mathrm{C}\right]$ glutamate and

$$
\left[{ }^{14} \mathrm{C}\right] \text { malate }
$$

The bacteroids ( $1 \mathrm{ml}$ suspension) were incubated with $5 \mathrm{ml}$ assay medium containing $2 \mathrm{mM}-(5 \mu \mathrm{Ci}, 0.185 \mathrm{MBq})\left[\mathrm{U}-{ }^{14} \mathrm{C}\right]$ aspartate, [U-1 ${ }^{14} \mathrm{C}$ glutamate or $\left[\mathrm{U}-{ }^{14} \mathrm{C}\right]$ malate under $1.0 \% \mathrm{O}_{2}$ in $\mathrm{N}_{2}$ for 20 min. Data are expressed as means \pm SE of duplicate experiments.

\begin{tabular}{lccc}
\hline \hline & \multicolumn{3}{c}{ Incorporation of ${ }^{1+} \mathrm{C}\left(10^{-3} \times\right.$ d.p.m. $)$} \\
\cline { 2 - 4 } Substrate & Aspartate & Glutamate & Malate \\
\hline Neutral & $106 \pm 19.6$ & $70.5 \pm 7.9$ & $414 \pm 7.0$ \\
Anionic & $64.1 \pm 4.4$ & $74.7 \pm 4.5$ & $146 \pm 16.6$ \\
Cationic & $381 \pm 0.6$ & $609 \pm 14.8$ & $432 \pm 41.2$ \\
Cationic fraction & & & \\
Asp & $3.88 \pm 0.37$ & $3.89 \pm 1.32$ & $7.77 \pm 1.80$ \\
Ser & $5.92 \pm 0.45$ & $11.2 \pm 2.58$ & $8.52 \pm 0.05$ \\
Asn & $0.69 \pm 0.13$ & $0.33 \pm 0.14$ & $1.33 \pm 0.94$ \\
Glu & $192 \pm 11.4$ & $286 \pm 34.1$ & $97.4 \pm 18.1$ \\
Gln & $2.37 \pm 0.10$ & $1.58 \pm 1.36$ & $2.87 \pm 1.79$ \\
Gly & $2.13 \pm 0.02$ & $2.12 \pm 0.47$ & $3.18 \pm 1.62$ \\
Ala & $3.27 \pm 0.18$ & $2.72 \pm 1.18$ & $3.65 \pm 0.40$ \\
Val & $1.81 \pm 0.09$ & $2.31 \pm 0.27$ & $2.38 \pm 0.25$ \\
Leu & $3.56 \pm 0.17$ & $3.14 \pm 0.08$ & $7.16 \pm 0.29$ \\
GABA & $3.84 \pm 1.05$ & $4.56 \pm 1.56$ & $4.54 \pm 0.46$ \\
\hline \hline
\end{tabular}

extremely low activity in bacteroids as compared with plant cell cytosol. However, the activities of two other enzymes involved in the GABA shunt, GABA-AT and SSDH, were tenfold higher in bacteroids than in plant cytosol. GABA-AT in bacteroids was more active with pyruvate and oxaloacetate than with 2-oxoglutarate, unlike the situation in cowpea Rhizobium sp. MNF2030 (Jin et al., 1990) and R. meliloti bacteroids (Miller et al., 1991). 
Table 6. Amino acid contents in bacteroids after incubation with malate, glutamate, or malate + glutamate

One $\mathrm{ml}$ bacteroid suspension was incubated with $5 \mathrm{ml}$ assay medium with or without exogenous substrates for 20 min under $1.5 \% \mathrm{O}_{2}$ in $\mathrm{N}_{2}$ and amino acid content was measured (B). The net increase in amino acids in the medium during the incubation was also determined (M). All data are means of duplicate experiments (LSD, least significant difference).

\begin{tabular}{|c|c|c|c|c|c|c|c|c|c|c|}
\hline \multirow{3}{*}{$\begin{array}{l}\text { Amino } \\
\text { acid }\end{array}$} & \multicolumn{10}{|c|}{ Amino acid content $\left[\mathrm{nmol}(\mathrm{mg} \text { protein })^{-1}\right]$ after incubation with: } \\
\hline & \multicolumn{2}{|c|}{ None } & \multicolumn{2}{|c|}{$\begin{array}{l}\text { Malate } \\
(2 \mathrm{mM})\end{array}$} & \multicolumn{2}{|c|}{$\begin{array}{l}\text { Glutamate } \\
(2 \mathrm{mM})\end{array}$} & \multicolumn{2}{|c|}{$\begin{array}{l}\text { Malate }(2 \mathrm{mM})+ \\
\text { Glutamate }(1 \mathrm{mM})\end{array}$} & \multicolumn{2}{|c|}{$\operatorname{LSD}(5 \%)$} \\
\hline & B & $\mathbf{M}$ & B & $\mathbf{M}$ & B & $\mathbf{M}$ & B & $\mathbf{M}$ & B & $\mathbf{M}$ \\
\hline Asp & $0 \cdot 3$ & 0 & 0.6 & 0 & $0 \cdot 5$ & $4 \cdot 3$ & $0 \cdot 5$ & $15 \cdot 1$ & 0.32 & $0 \cdot 01$ \\
\hline Thr & 1.4 & 0.3 & $1 \cdot 2$ & 0.5 & $1 \cdot 2$ & 0.5 & 0.9 & 0.7 & 0.34 & 0.81 \\
\hline Ser & 0.4 & 0 & $1 \cdot 1$ & 0.2 & 0.3 & 0.2 & $0 \cdot 3$ & 0.6 & 0.22 & 0.42 \\
\hline Glu & 8.7 & 0 & $13 \cdot 1$ & 0 & 24.9 & - & $23 \cdot 2$ & - & $6 \cdot 12$ & - \\
\hline Gly & 0.6 & 0 & 1.0 & 0.2 & 0.5 & 0 & 0.6 & 0.4 & 0.55 & 0.01 \\
\hline Ala & $1 \cdot 1$ & 0 & $2 \cdot 0$ & $2 \cdot 2$ & $1 \cdot 6$ & 0.3 & $2 \cdot 5$ & $9 \cdot 2$ & 0.54 & 2.69 \\
\hline Val & 2.7 & $2 \cdot 1$ & $2 \cdot 1$ & $2 \cdot 3$ & $2 \cdot 0$ & $2 \cdot 2$ & 1.8 & $2 \cdot 6$ & 0.45 & 1.08 \\
\hline Ile & 0.7 & 1.7 & 0.5 & 1.4 & 0.6 & 1.8 & 0.5 & 1.7 & 0.13 & 0.57 \\
\hline Leu & 0.7 & 1.7 & 0.5 & $1 \cdot 6$ & $0 \cdot 6$ & 1.9 & 0.5 & 1.9 & 0.12 & 0.91 \\
\hline GABA & 0.2 & 0 & $0 \cdot 3$ & 0 & 0.2 & 0 & 0.3 & 0 & 0.07 & - \\
\hline Lys & $4 \cdot 5$ & 0.6 & $3 \cdot 6$ & 0.4 & $4 \cdot 1$ & 0.5 & $3 \cdot 2$ & $0 \cdot 5$ & $1 \cdot 25$ & 1.38 \\
\hline Arg & 2.6 & 0.7 & $2 \cdot 0$ & 0.6 & $2 \cdot 5$ & 0.6 & 1.9 & 0.7 & 0.95 & 0.46 \\
\hline Pro & 1.6 & 0.5 & 1.8 & 0.9 & 1.8 & 1.0 & 1.5 & $1 \cdot 3$ & 0.34 & $1 \cdot 16$ \\
\hline
\end{tabular}

Table 7. Enzyme activities related to glutamate catabolism in plant cell cytosol and bacteroids of soybean root nodules

Data are expressed as means \pm SE of duplicate assays. The assay system is described in Methods.

\begin{tabular}{|c|c|c|c|}
\hline \multirow[b]{2}{*}{ Enzyme } & \multirow{2}{*}{$\begin{array}{l}\text { Cofactor/ } \\
\text { substrate }\end{array}$} & \multicolumn{2}{|c|}{$\begin{array}{c}\text { Enzyme activity } \\
{\left[\mathrm{nmol}(\mathrm{mg} \text { protein })^{-1}\right.} \\
\left.\mathrm{min}^{-1}\right]\end{array}$} \\
\hline & & Cytosol & Bacteroid \\
\hline $\begin{array}{l}\text { Succinic semialdehyde } \\
\text { dehydrogenase }\end{array}$ & $\begin{array}{l}\text { NAD } \\
\text { NADP }\end{array}$ & $\begin{array}{l}0.73 \pm 0.03 \\
0.97 \pm 0.06\end{array}$ & $\begin{array}{l}34 \pm 3 \cdot 3 \\
32 \pm 1 \cdot 9\end{array}$ \\
\hline $\begin{array}{l}\text { Glutamate } \\
\text { decarboxylase }\end{array}$ & & $0 \cdot 12 \pm 0 \cdot 14$ & $0.64 \pm 0.01$ \\
\hline $\begin{array}{l}\text { GABA amino- } \\
\text { transferase }\end{array}$ & $\begin{array}{l}\text { Pyr } \\
\text { OAA } \\
2-O G\end{array}$ & $\begin{array}{l}0.12 \pm 0.12 \\
0.14 \pm 0.02 \\
0.04 \pm 0.01\end{array}$ & $\begin{array}{r}2 \cdot 1 \pm 0.44 \\
2 \cdot 4 \pm 0 \cdot 32 \\
0 \cdot 11 \pm 0 \cdot 06\end{array}$ \\
\hline $\begin{array}{l}\text { Glutamate } \\
\text { dehydrogenase }\end{array}$ & & $6 \cdot 6 \pm 0 \cdot 36$ & $4 \cdot 1 \pm 0.04$ \\
\hline $\begin{array}{l}\text { Aspartate- } \\
\text { oxoglutarate } \\
\text { aminotransferase }\end{array}$ & & $120 \pm 11 \cdot 2$ & $90 \pm 1 \cdot 9$ \\
\hline $\begin{array}{l}\text { Alanine-oxoglutarate } \\
\text { aminotransferase }\end{array}$ & & $89 \pm 4 \cdot 0$ & $6.6 \pm 0.56$ \\
\hline
\end{tabular}

Pyr, pyruvate; OAA, oxaloacetate; 2-OG, 2-oxoglutarate.

Permeability of the PBM to malate and glutamate was indirectly examined by comparing respiratory evolution of ${ }^{14} \mathrm{CO}_{2}$ from ${ }^{14} \mathrm{C}$-labelled substrates by intact PBUs with that by naked bacteroids (Fig. 3). The purity of PBUs isolated in this work was comparable to that shown by Price et al. (1987) and the disruption of PBUs after 40 min incubation with gentle rocking was almost negligible as checked by light and electron microscopy (data not shown). Rates of respiratory utilization of $\left[{ }^{14} \mathrm{C}\right]$ malate by intact PBUs were about $60 \%$ of those by naked bacteroids at both concentrations of 0.1 and $2 \mathrm{mM}$. On the other hand, evolution of ${ }^{14} \mathrm{CO}_{2}$ from $\left[{ }^{14} \mathrm{C}\right]$ glutamate by the PBUs was less than $15 \%$ of that by naked bacteroids at a concentration of $0.1 \mathrm{~mm}$, but about $45 \%$ of that at $2 \mathrm{~mm}$.

\section{Discussion}

The results of ${ }^{15} \mathrm{~N}$ and ${ }^{14} \mathrm{C}$ tracer experiments suggest that aspartate and glutamate are both actively oxidized by the TCA cycle after release of amino nitrogen, which is rapidly lost from bacteroids as $\mathrm{NH}_{3}$. The supply of AOA greatly inhibited amino-transfer reactions in bacteroids as demonstrated by the ${ }^{15} \mathrm{~N}$ labelling experiment (Table 3). In addition, AOA had no inhibitory effect on the transport of both glutamate and aspartate in the preliminary uptake assay of $\left[{ }^{14} \mathrm{C}\right]$ glutamate and $\left[{ }^{14} \mathrm{C}\right]$ aspartate (data not shown). The strong inhibition of glutamate utilization with AOA, therefore, indicates that glutamate catabolism in bacteroids involves a transamination process(es) as an essential step, and GDH in the bacteroids does not operate in the direction of oxidative deamination. Recently, Salminen \& Streeter (1990) also suggested that GDH in soybean nodule bacteroids operates in vivo in the direction of glutamate formation in spite of the presence of a large pool of glutamate. When $\left[{ }^{14} \mathrm{C}\right]$ malate was supplied to bacter- 


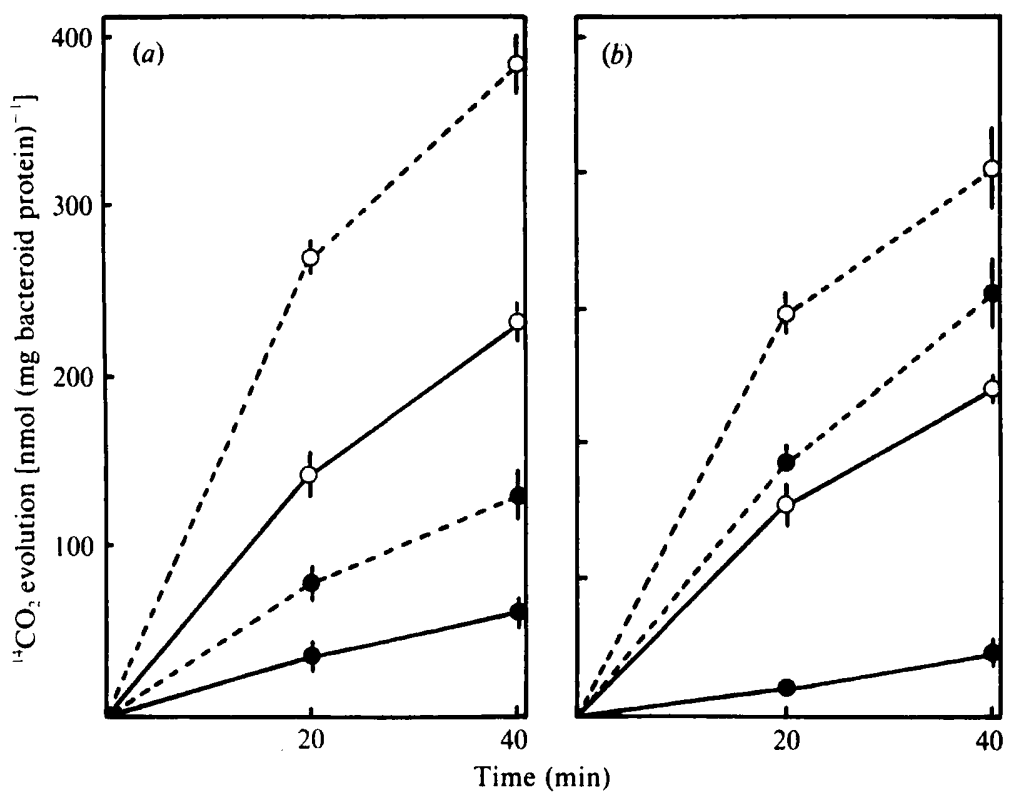

Fig. 3. Respiratory utilization of $\left[U^{-14} \mathrm{C}\right]$ malate $(\mathrm{O})$ and $\left[\mathrm{U}^{14} \mathrm{C}\right.$ ]glutamate $(O)$ by the intact PBUs isolated from soybean root nodules. The PBUs (solid lines) and naked bacteroids (broken lines) were incubated with ${ }^{14} \mathrm{C}$-labelled substrates $(5 \mu \mathrm{Ci}, 0.185 \mathrm{MBq})$ at concentrations of $2 \mathrm{mM}(a)$ or $0.1 \mathrm{mM}(b)$, and ${ }^{1+} \mathrm{CO}_{2}$ evolved was determined. Data are expressed as means of duplicate incubations. Vertical bars indicate $2 \times$ SE. The assay system is described in Methods. oids, substantial incorporation of ${ }^{14} \mathrm{C}$ into glutamate was found (Table 5), also suggesting the formation of glutamate from 2-oxoglutarate in the bacteroids.

On the contrary, utilization of exogenous aspartate by bacteroids was not significantly affected by AOA. This indicates that the major pathway of aspartate utilization was via the TCA cycle after direct deamination. The presence of substantial activity of aspartase in bacteroids (Table 4) suggests that this enzyme is responsible for the direct deamination of aspartate. Effects of AOA on ${ }^{15} \mathrm{~N}$ abundance in $\mathrm{NH}_{3}$ released from the bacteroids fer $\left[{ }^{15} \mathrm{~N}\right]$ glutamate or $\left[{ }^{15} \mathrm{~N}\right]$ aspartate (Table 3 ) also strongly suggest the involvement of transaminations in glutamate catabolism but not in aspartate utilization.

Amino-transfer to oxaloacetate is the most probable first reaction in glutamate catabolism in bacteroids because of the presence of relatively high activity of aspartate-oxoglutarate aminotransferase (Table 7; see also Salminen \& Streeter, 1990). Nitrogen derived from glutamate would need to be released from the bacteroids by rapid deamination of aspartate. That ${ }^{15} \mathrm{~N}$ abundance in aspartate in the bacteroids fed $\left[{ }^{15} \mathrm{~N}\right]$ glutamate was significantly lower than in released $\mathrm{NH}_{3}$ seems to conflict with this hypothesis. However, it should be noted that very little incorporation of ${ }^{15} \mathrm{~N}$ into aspartate in the bacteroids was found even when they were incubated with [ ${ }^{15} \mathrm{~N}$ ] aspartate, despite rapid labelling of glutamate and $\mathrm{NH}_{3}$ released (Tables 2 and 3). Further, the $\left[{ }^{14} \mathrm{C}\right]$ aspartate feeding experiment resulted in no significant incorporation of ${ }^{14} \mathrm{C}$ into aspartate in the bacteroids (Table 6), although it was actively respired (Fig. 2). Salminen \& Streeter (1987) also reported that ${ }^{14} \mathrm{C}$ from exogenously supplied $\left[{ }^{14} \mathrm{C}\right]$ aspartate was not incorporated into the bacteroid aspartate pool, although a substantial amount of ${ }^{1+} \mathrm{C}$ appeared in $\mathrm{CO}_{2}$ respired. These findings indicate that the active pool of aspartate may be extremely small and separated from the large inactive pool in the bacteroids. Exogenously supplied aspartate could be catabolized by bacteroids without being incorporated into their major (inactive) aspartate pool; by contrast glutamate was catabolized after incorporation into the large glutamate pool in the bacteroids.

When bacteroids were incubated with both malate and glutamate, large amounts of aspartate and alanine, particularly aspartate, were released from the bacteroids to the incubation medium (Table 6). Aspartate in the medium was not, or only slightly detectable when the bacteroids were fed malate or glutamate alone, and glutamate was not released from bacteroids incubated with malate. These findings also indicate that in bacteroids aspartate is formed by transamination from glutamate, and furthermore suggest that in intact nodules, where $\mathrm{C}_{4}$-dicarboxylates are available for bacteroid respiration as more abundant and effective substrates, aspartate need not be imported into bacteroids from plant cytosol. The physiological significance of liberation of alanine from the bacteroids is unclear, but exogenous alanine did not support the bacteroid respiration (Table 1). One of the possible routes of $\mathrm{NH}_{3}$ liberation from glutamate is a chain of glutamateoxaloacetate aminotransferase and aspartate-pyruvate aminotransferase with alanine dehydrogenase as suggested in Rhizobium sp. MNF2030 (Jin et al., 1990). Even though such a chain of transaminases with a terminal amino acid dehydrogenase may be also partly 
responsible in glutamate catabolism in soybean nodule bacteroids, the data in this study strongly suggest that the major pathway of $\mathrm{NH}_{3}$ liberation from exogenously supplied glutamate is amino-transfer to form aspartate followed by direct deamination of aspartate by aspartase, as discussed above.

One of the major alternative pathways of glutamate catabolism is the 4-aminobutyrate pathway (GABAshunt). Operation of the GABA-shunt was recently reported in $R$. meliloti bacteroids (Miller et al., 1991). In $B$. japonicum bacteroids, however, it is suggested that the GABA-shunt does not operate because of the lack of GDC activity (Salminen \& Streeter, 1990). In the present work GDC activity in the bacteroids was very low but detectable (net radioactivity in GABA formed in a standard GDC assay was about 2.5-fold of control) and activities of two other GABA-shunt enzymes, GABAAT and SSDH, were more than tenfold higher in bacteroids than in the plant cytosol (Table 7). Very similar values of ${ }^{15} \mathrm{~N}$ abundances in GABA and glutamate throughout the labelling period (Table 2) suggest that GABA is formed directly from glutamate in the bacteroids. The low radioactivity of GABA formed from $\left[{ }^{14} \mathrm{C}\right]$ glutamate (Table 5) could be due to the extremely low concentration of GABA in the bacteroids (Table 6) and the high activities of GABA-AT and SSDH in the bacteroids. Furthermore, our previous work using a ${ }^{13} \mathrm{C}$-labelling technique indicated a relatively high turnover rate of the carbons of GABA in bacteroids (Kouchi \& Yoneyama, 1986). Thus, the overall results of tracer experiments and enzyme assays suggest that the GABA-shunt may be responsible for a small fraction of the glutamate catabolism of bacteroids. Since exogenous GABA does not stimulate bacteroid activities (Table 1), transport of GABA to bacteroids from plant cytosol is unlikely even though soybean nodule cytosol contains a considerable amount of GABA (Kouchi \& Yoneyama, 1986).

A possibility that glutamate is one of the in vivo carbon sources for bacteroids can be criticized because the PBM may be impermeable to glutamate. It was observed that the PBM prevented the supply of glutamate to enclosed bacteroids when intact PBUs were incubated with $0.1 \mathrm{~mm}$-glutamate, though free bacteroids possess a high affinity transport system for glutamate (Udvardi et al., 1988). We also examined the utilization of malate and glutamate by PBUs isolated from soybean nodules (Fig. 4). The respiratory evolution of ${ }^{14} \mathrm{CO}_{2}$ from $0 \cdot 1 \mathrm{~mm}$ $\left[{ }^{14} \mathrm{C}\right]$ glutamate by bacteroids was severely inhibited by the presence of the PBM enclosing the bacteroids. However, when the PBUs were supplied with $\left[{ }^{14} \mathrm{C}\right]$ glutamate at a concentration of $2 \mathrm{mM}$, the respiratory utilization of glutamate by the enclosed bacteroids was about $45 \%$ of that by free bacteroids, whereas malate utilization was also inhibited to about $60 \%$ by the presence of the PBM. In soybean nodules estimates of the in vivo concentration of glutamate in the plant cell cytosol range from 1 to $10 \mathrm{~mm}$ (Kouchi \& Yoneyama, 1986; Streeter, 1987; Bergersen \& Turner, 1988). Therefore, the PBM may not work as a potential barrier to the supply of glutamate to the bacteroids from plant cytosol within the range of concentrations expected in vivo in the cytosol in nodules.

The authors wish to express their thanks to Dr S. Tajima of Kagawa University, Kagawa, Japan for his helpful discussions throughout this study. They also thank Mrs T. Miura for her technical assistance in plant cultivation and nodule harvesting. This work was supported financially by a fund from The Ministry of Agriculture, Forestry and Fisheries, Japan (BMP 91-V-1-1).

\section{References}

Bergersen, F. J. \& Turner, G. L. (1967). Nitrogen fixation by the bacteroid fraction of breis of soybean root nodules. Biochimica et Biophysica Acta 141, 507-515.

Bergersen, F. J . \& Turner, G. L. (1988). Glutamate as a carbon source for $\mathrm{N}_{2}$-fixing bacteroids prepared from soybean root nodules. Journal of General Microbiology 134, 2441-2448.

Bradford, M. M. (1976). A rapid and sensitive method for the quantitation of microgram quantities of protein utilizing the principle of protein-dye binding. Analytical Biochemistry 72, 248254.

DuNN, S. D. \& Klucas, R. V. (1973). Studies on possible routes of ammonium assimilation in soybean root nodule bacteroids. Canadian Journal of Microbiology 19, 1493-1499.

Emerich, D. W., Ruiz-Argueso, T., Ching, T. M. \& Evans, H. J. (1979). Hydrogen-dependent nitrogenase and ATP formation in Rhizobium japonicum bacteroids. Journal of Bacteriology 137, 153160.

Finan, T. M., WoOd, J. M. \& Jordan, D. C. (1983). Symbiotic properties of $\mathrm{C} 4$ dicarboxylic acid transport mutants of Rhizobium leguminosarum. Journal of Bacteriology 154, 1403-1413.

FrenEy, J. R. \& Gibson, A. H. (1975). Accumulation of 4aminobutyrate in Trifolium subterraneum root nodules: effect of Rhizobium trifolii strain on aminotransferase activity. Australian Journal of Plant Physiology 2, 663-668.

GlenN, A. R. \& BREWIN, N. J. (1981). Succinate-resistant mutants of Rhizobium leguminosarum. Journal of General Microbiology 126, 237241.

Holtum, J. A. M. \& Winter, K. (1982). Activity of enzymes of carbon metabolism during the induction of crassulacean acid metabolism in Mesembryanthemum crystallium L. Planta 155, 8-16.

JiN, H. N., DilworTH, M. J. \& GlenN, A. R. (1990). 4-aminobutyrate is not available to bacteroids of cowpea Rhizobium MNF2030 in snake bean nodules. Archives of Microbiology 153, 455-462.

KaHN, M. L., Kraus, J. \& Somerville, J. E. (1985). A model of nutrient exchange in the Rhizobium-legume symbiosis. In Nitrogen Fixation Research Progress, pp. 193-199. Edited by H. J. Evans, P. J. Bottomley \& W. J. Newton. Dordrecht: Martinus Nijhoff.

Kano, H., Yoneyama, T. \& Kumazawa, K. (1975). Emission spectrometric ${ }^{15} \mathrm{~N}$ analysis of the amino acids and amides in plant tissues separated by thin layer chromatography. Analytical Biochemistry 67, 327-331.

Kimura, I. \& Tajima, S. (1989). Presence and characteristics of NADP-malic enzyme in soybean nodule bacteroids. Soil Science and Plant Nutrition 35, 271-279. 
KouchI, H. \& FUKAI, K. (1989). Rapid isolation of bacteroids from soybean root nodules by Percoll discontinuous gradient centrifugation. Soil Science and Plant Nutrition 35, 301-305.

Kouchi, H. \& Yoneyama, T. (1984). Dynamics of carbon photosynthetically assimilated in nodulated soya bean plants under steady-state conditions. 2. The incorporation of ${ }^{13} \mathrm{C}$ into carbohydrates, organic acids, amino acids and some storage compounds. Annals of Botany $53,883-896$.

Kouchi, H. \& Yoneyama, T. (1986). Metabolism of $\left[{ }^{13} \mathrm{C}\right.$-labelled photosynthate in plant cytosol and bacteroids of root nodules of Glycine max. Physiologia Plantarum 68, 238-244.

LEPAGE, G. A. (1964). Manometric and chemical estimation of metabolites and enzyme systems. In Manometric Techniques, pp. 208209. Edited by W. W. Umbreit, R. H. Burris \& J. F. Stauffer. Minneapolis: Burgess Publishing Company.

Macko, S. A., Estep, M. L. F., Engel, M. H. \& Hare, P. E. (1983). Stable nitrogen isotope effects in the transamination of amino acids. Carnegie Institution of Washington Year Book 82, 394-398.

Miller, R. W., MCRAE, D. G. \& JoY, K. (1991). Glutamate and 4aminobutyrate metabolism in isolated Rhizobium meliloti bacteroids. Molecular Plant-Microbe Interactions 4, 37-45.

Mori, S., Nishimura, Y. \& UCHINo, H. (1977). Rapid fluorogenic detection of ${ }^{14} \mathrm{C}$-amino acids on TLC. Journal of the Science of Soil and Manure, Japan 48, 332 (in Japanese).

Price, G. D., DAY, D. A. \& Gresshoff, P. M. (1987). Rapid isolation of intact peribacteroid envelopes from soybean nodules and demonstration of selective peameability to metabolites. Journal of Plant Physiology 130, 157-164.

Reinero, A., Shearer, G., Bryan, B. A., Skeeters, J. L. \& Kohl, D. H. (1983). Site of natural ${ }^{15} \mathrm{~N}$ enrichment of soybean nodules. Plant Physiology 72, 256-258.

Ronson, C. W., Lyttleton, P. \& Robertson, J. G. (1981). C $4^{-}$ dicarboxylate transport mutants of Rhizobium trifolii form ineffective nodules on Trifolium repens. Proceedings of National Academy of Sciences of the United States of America 78, 4284-4288.

Salminen, S. O. \& Streeter, J. G. (1987). Involvement of glutamate in the respiratory metabolism of Rhizobium japonicum bacteroids. Journal of Bacteriology 169, 495-499.
Salminen, S. O. \& Streeter, J. G. (1990). Factors contributing to the accumulation of glutamate in Bradyrhizobium japonicum bacteroids under microaerobic conditions. Journal of General Microbiology 136, 2119-2126.

Streeter, J. G. (1987). Carbohydrate, organic acid and amino acid composition of bacteroids and cytosol from soybean nodules. Plant Physiology 85, 768-773.

Streeter, J. G. \& ThOMPSON, J. F. (1972). In vivo and in vitro studies on $\gamma$-aminobutyric acid metabolism with the radish plant (Raphanus sativus L.). Plant Physiology 49, 579-584.

Tajima, S., Kimura, I. \& SaSahara, H. (1986). Succinate metabolism of isolated soybean nodule bacteroids at low oxygen concentration. Agricultural and Biological Chemistry 50, 1009-1014.

Tajima, S., Kimura, I., Kouzai, K. \& Kasal, T. (1990). Succinate degradation through the citric acid cycle in Bradyrhizobium japonicum J501 bacteroids under low oxygen concentrations. Agricultural and Biological Chemistry 54, 891-897.

ToKushige, M. (1985). Aspartate ammonia-lyase. Methods in Enzymo$\log y 113,618-627$.

Tuzimura, K. \& Meguro, H. (1960). Respiration substrates of rhizobium in the nodules. Journal of Biochemistry 47, 391-397.

UdVARDI, M. K., SAlom, C. L. \& DAY, D. A. (1988). Transport of Lglutamate across the bacteroid membrane but not the peribacteroid membrane from soybean root nodules. Molecular Plant-Microbe Interactions 1, 250-254.

WANG, D. (1960). An ion-exchange resin method for the fractionation of alcoholic plant extracts. Nature, London 186, 326-327.

Weatherburn, M. W. (1967). Phenol-hypochlorite reaction for determination of ammonia. Analytical Chemistry 39, 971-974.

Yoneyama, T., ARima, Y. \& Kumazawa, K. (1975). Sample preparation from dilute ammonium solution for emission spectrographic analysis of heavy nitrogen. Journal of the Science of Soil and Manure, Japan 46, 146-147 (in Japanese).

Yoneyama, T., Ladha, J. K. \& Watanabe, I. (1987). Nodule bacteroids and Anabaena: natural ${ }^{15} \mathrm{~N}$ enrichment in the legumeRhizobium and Azolla-Anabaena symbiotic systems. Journal of Plant Physiology 127, 251-259. 